Cahiers $d u$ MONDE RUSSE

\section{Cahiers du monde russe}

Russie - Empire russe - Union soviétique et États indépendants

$52 / 1 \mid 2011$

Varia

\title{
"I saw the light": Former Protestant believer testimonials in the Soviet Union, 1957-1987
}

"J'ai vu la lumière " : témoignages d'anciens protestants en Union soviétique, 1957-1987

\section{Emily Baran}

\section{(2) OpenEdition}

\section{Journals}

Édition électronique

URL : https://journals.openedition.org/monderusse/9325

DOI : 10.4000/monderusse. 9325

ISSN : $1777-5388$

Éditeur

Éditions de l'EHESS

Édition imprimée

Date de publication : 5 mars 2011

Pagination : 163-184

ISBN : 978-2-7132-2351-8

ISSN : $1252-6576$

Référence électronique

Emily Baran, " "I saw the light": Former Protestant believer testimonials in the Soviet Union,

1957-1987 ", Cahiers du monde russe [En ligne], 52/1 | 2011, mis en ligne le 28 mars 2014, consulté le 02 septembre 2022. URL : http://journals.openedition.org/monderusse/9325 ; DOI : https://doi.org/ $10.4000 /$ monderusse. 9325

Ce document a été généré automatiquement le 2 septembre 2022.

Tous droits réservés 


\title{
"I saw the light": Former Protestant believer testimonials in the Soviet Union, 1957-1987
}

\author{
"J'ai vu la lumière » : témoignages d'anciens protestants en Union soviétique,
} 1957-1987

Emily Baran

1 This statement by a former Baptist, published in a volume of stories from former believers in 1958, reflects a major shift in religious policy in the Soviet Union that began after the death of Josef Stalin in 1953. Under Nikita Khrushchev (1953-1964), the Soviet state launched a new effort to combat religious belief without recourse to the mass imprisonment and exile employed by the Stalinist state. For Khrushchev, the continued presence of religious belief in the Soviet Union represented a serious barrier to the achievement of communism. While socialism had allegedly eliminated the class basis for religion in the Soviet Union, Khrushchev recognized that religion would not die out of its own accord, but would require the active intervention of the state to destroy this "survival" (perezhitok) from the capitalist past. Making antireligious propaganda a major feature of his religious policy, he promoted the idea that with the proper atheist education, believers could be convinced to reject religious beliefs and embrace communist ideology instead. ${ }^{2}$

2 This strategy found reflection in the press, which became a critical organ for promoting antireligious propaganda. Having denounced previous press coverage of religion as too abstract, theoretical, and disconnected from local conditions, the state exhorted newspapers to explain to their readers the specific beliefs and practices of individual religions and to tailor their coverage to reflect the distinct religious communities in their respective districts and republics. In keeping with this practice, newspapers also reported on the lives of religious believers in their communities, taking a two-pronged approach in such articles. While denouncing the nefarious deeds of corrupt clergy and religious leaders, they depicted rank-and-file members as victims of religion who must 
patiently and non-judgmentally be encouraged to renounce their faith and rejoin Soviet society.

3 To accomplish the latter task, the press provided living proof of these allegedly loyal, but gullible Soviet believers who had been led astray by a few fanatics and leaders. Newspaper-scripted testimonials from former believers thus became a defining feature of the post-Stalin press's treatment of religion. District and regional newspapers published thousands of articles by former believers renouncing their faith and encouraging others to follow their example. They share a common narrative structure: Personal hardship and ignorance make citizens vulnerable to proposed religious solutions to their problems. They join a "sect" hoping to find acceptance and answers to their problems. ${ }^{4}$ Having joined, they gradually come to realize the organization's political aims, hypocrisy, and/or criminal activities. The former believers' growing doubt in the organization is coupled with doubts about its religious doctrine, which ultimately leads to a decision to leave the sect. This separation allows the former believers to reintegrate into Soviet society as "converted atheists." They now can achieve happiness and a purpose in life through building communism.

This article dissects former believer narratives from the Khrushchev era until the rise to power of Mikhail Gorbachev (1985-1991). While state religious policy evolved significantly throughout this time frame, former believer testimonials showed remarkable constancy in content and style. In particular, the article explores testimonials from former Protestants, a broad category that included Baptists, by far the largest Soviet denomination, as well as Seventh-Day Adventists, Pentecostals, and Jehovah's Witnesses, the smallest of these communities. ${ }^{5}$ Despite the denominational differences, the narrative plots of these stories are strikingly similar. ${ }^{6}$ While the press also published stories by former Orthodox believers, in particular former priests, nuns, and monks, they vary significantly from those written by Protestants and deserve a separate study. My sample comprises hundreds of articles published in regional (oblast') and republic newspapers in the post-Stalin era through the mid-1980s. It also includes articles published in several district (raion) newspapers in Soviet Moldavia, where a relatively high level of religious belief resulted in a large volume of such narratives. ${ }^{7}$ Lastly, I draw from believer narratives published in book-length collections and in the nationally-distributed atheist magazines Nauka $i$ religiia [Science and Religion] and Liudyna i svit [Man and the World].

\section{Khrushchev's New Religious Policy}

5 In the late Stalin era, religion received little attention in the Soviet press, despite continued criminal prosecution of believers for state crimes and the wholesale exile of Witnesses from the western borderlands in 1949 and 1951. The general resurgence in newspaper coverage of religion began with Khrushchev's Hundred Days campaign against religion in 1954. Although the state quickly pulled back from the campaign, citing overzealous local officials, Khrushchev did not abandon his new religious policy, relaunching it in the late 1950s with greater success. ${ }^{8}$ Khrushchev argued that while the Soviet state had eliminated the economic wealth and political power of the church, religious superstition lingered among the population, particularly in rural areas and among older citizens. The wartime annexation of new territories, particularly western Ukraine, had aggravated this problem by greatly increasing the number of churches and 
active believers in the Soviet Union. To undo this postwar religious growth, Khrushchev ordered the closing of over five thousand churches, a move that primarily affected the Russian Orthodox Church. ${ }^{9}$ At the same time, Khrushchev argued that in order to eliminate religious belief entirely, the Party needed to make a major investment of time and resources into "scientific" atheist propaganda and agitation. In particular, Party activists must explain to believers the falsity of religion and the superiority of communist ideology without offending them and with minimal recourse to coercive measures against ordinary believers. ${ }^{10}$ To realize this goal, the Party-state sharply increased funding for antireligious propaganda and the study of scientific atheism. ${ }^{11}$ It did not, however, abandon the use of criminal prosecution against believers, a practice that continued into the Gorbachev era.

The state also expanded state registration for Protestant religious communities that conformed to Soviet laws, granting organizations the right to hold services in officially designated houses of worship, while also increasing control over these religious bodies. Registration was not extended to all Protestant organizations. The state considered Witnesses, Adventist-Reformists, and many Pentecostals to be "anti-state and fanatical in character" and barred them from registration. Baptist congregations, though granted this right, were divided over the issue of registration, which some refused due to the risk of being coopted by the state. ${ }^{12}$ As a whole, registration rewarded those religious organizations that agreed to cooperate with the state and not challenge the official ideology, while marginalizing those who did not abide by these strictures.

7 The Soviet state used registration to justify its continued use of coercive measures against some believers. In its view, registration offered all legitimate religions the opportunity to practice their faith in accordance with Soviet laws. Those religious believers who did not register their congregations or whose actions violated the registration guidelines were criminals and deserved to be punished to the full extent of the law. In accordance with this interpretation, the state began stricter enforcement of the existing religious laws. ${ }^{13}$ Through the late 1950s, the state continued to use the Stalin-era approach of prosecuting believers under state crime statutes (Article 58), but in 1960, it modified the criminal code, introducing article 227, which mandated five-year prison terms or exile for persons engaging in religious activities that endangered public health, incited citizens not to fulfill their civic duties, or enticed minors. ${ }^{14}$ Under article 227 , members of unregistered religious organizations, particularly, but not exclusively, those in leadership positions, faced the constant threat of arrest and imprisonment.

The state promoted the view that those believers tried for illegal religious activities represented a tiny fraction of Soviet believers, most of whom were loyal to the state and abided by its laws. According to Khrushchev, the vast majority of believers had to be convinced to renounce their faith solely through patient and scientific atheist propaganda and agitation. Only a small minority of fanatics and unregistered religious leaders, who stubbornly refused to obey the law and whose actions endangered the state and its citizens, must be removed from society through criminal prosecution.

9 The 1964 ouster of Khrushchev from his position as General Secretary brought Leonid Brezhnev (1964-82) to power and ended certain elements of the antireligious campaigns. William Fletcher identifies two key changes to religious policy as a result of Khrushchev's removal from the Party leadership: the end to massive church closures and the more selective use of "force" against believers..$^{15}$ Under Brezhnev, the state focused on gradual improvements in atheist educational work and on increasing control over 
both registered and unregistered religious organizations. The policy change mirrored the new priorities of the Brezhnev state, marked by an emphasis on foreign policy, domestic stability, and a crackdown on dissidents. Yet the actual content of atheist work on the ground level often varied little, if at all, from that of the Khrushchev era. As anthropologist Alexei Yurchak notes about the late Soviet era, "The form of ideological representations - documents, speeches, ritualized practices, slogans, posters, monuments, and urban visual propaganda - became increasingly normalized, ubiquitous, and predictable." ${ }^{16}$ Yurchak's words offer an apt description of former believer narratives during this period.

\section{Drafting Former Believers}

10 In the postwar Stalin years, the state kept religion largely out of its newspapers and devoted minimal energy to antireligious propaganda and agitation. The few articles that did appear had little information on Soviet religious life, and certainly no acknowledgment of state repression of Protestant religious communities. The new, expansive religious reporting of the late 1950s marked a major departure from this strategy. The state hoped that increased social exposure of believers in their communities would encourage (or pressure) believers to conform to secular society and abandon their faith. Beginning with this second religious campaign and continuing until the late 1980s, former believer testimonials appeared regularly in the Soviet press as often as once a week in district newspapers.

11 The success of the new religious policy rested, in part, on the ability of the Soviet state to gain the trust of believers and win their hearts and minds for communism. The state repeatedly encouraged atheist agitators to commit to individual work with believers in their locales, a practice that meant engaging with and debating religious believers on a very direct level. This necessitated that agitators have detailed knowledge of the beliefs, practices, and history of specific religions, a problem given the dearth of accurate published information on Protestantism in the Soviet Union. ${ }^{17}$ In one embarrassing example, an atheist agitator spent an entire year convincing one believer to leave the Baptist religion. At the end of the year, she told him, "You've convinced me. I don't believe in Baptism." A short while later, the agitator learned that the woman in fact belonged to the Witnesses. ${ }^{18}$ Thus the press also needed to serve as a source of accurate information to improve the quality of antireligious propaganda and to teach agitators to distinguish between the myriad of religious organizations in their communities. Former believers offered a unique opportunity to bridge this information gap through their ability to reveal insider knowledge on belief systems, rituals, and practices. The state also hoped that believers might listen more readily to the words of former fellow members of their religion than they would to an atheist agitator. Ideally, the state would turn believers into atheists, and then redeploy them into agitation work, a sector in perpetual need of qualified cadres. Indeed, the press comprised only one outlet for former believers, who frequently told their stories multiple times and in multiple venues. Party activists invited these individuals to give talks to current believers. ${ }^{19}$ The state also used former believers as star witnesses for the prosecution in criminal trials against religious leaders. ${ }^{20}$ To increase the flow of former believers into agitation work, the state encouraged individuals to view public denunciation of religion as a necessary rite of passage in converting from Protestantism to an atheist worldview. 

Local officials often measured the success or failure of atheist agitation by the number of believers who had not only renounced religion, but had spoken publicly in the press. ${ }^{21}$ The number of former believers offered a more attractive yardstick for officials than the actual number of believers. As religion stubbornly refused to disappear in their communities, they could at least point to atheist testimonials as evidence that their propaganda efforts were having some positive impact. To encourage better results, a great deal of pressure could be placed on individual believers. A 1980 complaint from one Witness hints at this reality. He states that his city soviet told him that in order to get an apartment, he would need to denounce the Witnesses in the press. ${ }^{22}$ Another man had his driver's license taken until he agreed to renounce religion. ${ }^{23}$

thad been convinced to renounce religion, reporters and atheist agitars helped them to craft their stories into a framework that fit the goals of the new religious policy. As a result, former believer stories have a striking similarity in style and rhetoric that is not at all coincidental. Yurchak notes how Soviet newspapers commonly scripted letters to the editor, for example, in order to promote a specific message by the editorial board. ${ }^{24}$ Outside help in drafting these testimonials was further necessitated by the fact that some, mostly elderly, rural believers had little education and a few were even illiterate. The magazine Nauka i religiia, in a 1960 article detailing the steep rise in articles by former believers across the USSR, noted that many stories come from people "not used to holding a pen." ${ }^{25}$ In such cases, newspapers sometimes printed the signature of the person to denote his or her consent to the written version of the story that they had conveyed orally to an interviewer, or simply retold the story on behalf of the believer. ${ }^{26}$ Overall, the average religious believer, as portrayed in the narratives, lived in a small town or village, had not finished high school, and worked on a kolkhoz, in a factory, or was engaged in other unskilled manual labor. The ages varied widely, and both genders were well-represented.

Although the authorities manipulated these former believer testimonials, their authors stressed that they had written the stories of their own free will, and not under pressure from the state or for personal gain. ${ }^{27}$ While outside pressure certainly did exist in most scenarios, these stories came from real individuals who had been involved in religion. In some instances, the same people appeared in articles about religious believers prior to renouncing their beliefs. For example, a 1957 article accused a woman of having committed adultery with another believer and of having helped kidnap the man's stepchild. But in 1969, papers printed a glowing review of her memoirs, published soon after her break with religion. ${ }^{28}$ Also, since the majority of these articles were published in local papers, the reader might know the individuals in question. As a result, the names, dates, and broad plot of the narratives likely corresponded to real life events. Nevertheless, former believers undoubtedly were coached as to what to say and how to say it, and embellished events to reflect better on themselves and to demonize their former religion.

Former believer narratives reflect the wider importance of autobiographies and the selffashioning of identity after 1917. From private diaries to public petitions, Soviet citizens honed the art of constructing a personal life story that identified themselves as worthy of membership in the new Soviet society. As historian Jochen Hellbeck notes, a person's autobiography became "an artifact of considerable political weight." ${ }^{29}$ Numerous scholars have written about autobiographies and the larger process of self- 
transformation under Stalin. Many of their insights regarding this earlier narrative construction hold true for former believer testimonials in the post-Stalin era. Igal Halfin, for example, writes that "Communist life stories were always fabricated insofar as the author followed the official script... The author always hoped to present himself in the best light possible, not just to others, but to himself as well." ${ }^{30}$ This was certainly the case for former believers, whose stories follow a standard format and portray their authors in a sympathetic manner. Miriam Dobson has extended this scholarship into the early Khrushchev era, examining petitions for release and rehabilitation of prisoners and ex-prisoners to state officials. Dobson writes that these individuals had to "persuade officials that they were fit to be considered Soviet citizens once more and their status as outcasts was erroneous." ${ }^{31}$ Similarly, former believers wanted their fellow citizens and local authorities to see them as trustworthy members of society, despite their past involvement in a religious organization. Overall, Protestant former believer testimonials are best seen as one aspect of a broader tradition pervasive throughout Soviet society of constructing one's identity and personal life trajectory in line with the idealized image of the new Soviet man.

\section{Constructing the Narrative}

Testimonials from believers of multiple Protestant religions, and across decades of Soviet history, follow a remarkably uniform narrative arc and draw from a set phraseology. Most commonly, believers describe their lives as a journey from religion and toward the truth found only in communism..$^{32}$ They begin with an explanation of how they could have been convinced to join a sect in the first place. The most common factors were ignorance, poor education, personal hardship, and trickery on the part of preachers and clergy. Those believers living in western borderland territories annexed during World War II could describe growing up in extreme poverty without blaming the Soviet state, instead faulting conditions under Polish and Romanian rule, and under German occupation. Some of these individuals joined religious organizations prior to the arrival of Soviet power. Nikolai, a former Baptist, recounted how he had grown up in a poor peasant family in interwar Romania, working as a shepherd already at the age of six to help support his family. His parents died early in his childhood, leaving him at the mercy of relatives until he eventually found himself homeless and doing odd jobs to survive on the streets. When local evangelicals approached him with words of comfort, he found solace in religion and quickly joined the congregation. ${ }^{33}$

Personal trauma, frequently tied to experiences during World War II, created a sense of uncertainty and a longing for solutions to seemingly insoluble problems. By pinning religious conversion so heavily to wartime experiences, the state also depicted religiosity as born out of a specific historical context and therefore unlikely to repeat itself under normal, peacetime conditions. This narrative strategy downplayed the threat of religion and also placed its origins firmly in the past. However, as years passed, more narratives cited trauma unrelated to the war, including physical impairments, chronic disease, and family problems as explanations for conversion. Where modern medicine had failed to offer a cure, religious leaders stepped in with promises of miracles. One woman joined the Baptists after prayer seemed to aid her recovery from a dangerous operation..$^{34}$ Many accounts cite multiple traumatic incidents, which not only helped account for the person's conversion to religion, but also made them particularly 
sympathetic to readers. One woman, for instance, detailed how eight of her siblings died in childhood from famine or sickness, her mother turned to alcoholism, her father killed himself, her husband died young, and one of her daughters was electrocuted to death. She then related how religious leaders had preyed on her during her time of grief. ${ }^{35}$

Former believers also pointed to their lack of education as a reason for their religious conversion. Elderly believers or those who grew up in the western borderlands outside of Soviet rule blamed the legacy of tsarist or bourgeois educational institutions for their low levels of schooling. ${ }^{36}$ As time wore on, this justification no longer worked well, as many, if not most, Soviet believers had attended Soviet schools in their youth. At the same time, a large portion of young believers had grown up in religious households. These individuals tended instead to shift responsibility onto their parents, who they claimed had essentially brainwashed them as children, using fear of eternal punishment to inculcate religious belief. ${ }^{37}$ One young former believer, raised as a Baptist, recalls how his Sunday school teacher turned him and the other children against their secular teachers, teaching them to view themselves as "fighters for the truth" in their classrooms. ${ }^{38}$

Having converted, former believers now had the arguably more difficult task of explaining why they stayed, many of them for several decades. In general, they described their time in the organization as a slow journey from darkness to light, from ignorance to understanding, and from scorn for Soviet society to a desire to rejoin it. These motifs appear in nearly every story. A sampling of titles illustrates the ubiquity of such images: "I saw the light," "From darkness to life," "Toward the light," "Four Years in Darkness," and "Escape from darkness." ${ }^{39}$ Testimonials frequently referred to the years spent as members of religious organizations as being like a "dream" (or more frequently, a "nightmare") and religion itself as being akin to a "narcotic." ${ }^{40}$ They lived with a "blindfold" over their eyes, incapable of seeing reality or recognizing their misguided beliefs. ${ }^{41}$ Religion had captured their minds and enslaved them through fear and forced obedience. These bonds had to be broken so that believers could liberate themselves. ${ }^{42}$ One man entitled his story, "I became a free person again." 43

More concretely, members cited the same reasons for remaining believers as they had for joining religion in the first place. Lack of education made it more difficult for members to realize the falsity and hypocrisy of the religion's teachings. It justified why otherwise loyal Soviet citizens, having found themselves in antisocial organizations, often took several years, even decades, to leave. Believers also highlighted how religion isolated them from the surrounding community. Almost all stories noted how, during the time when the authors belonged to a religion, they did not read newspapers, watch TV, or listen to the radio. Religious leaders told them that the outside world was evil and must be avoided, instilling fear of eternal damnation for failure to adhere to these strict rules. Former believers recalled how the threat of eternal damnation paralyzed them, making them unwilling to listen to reason. ${ }^{44}$

21 Eventually, of course, former believers chronicled how they came to renounce their faith. They recalled a hunger for the truth that led them to reexamine their beliefs and question their membership in religious organizations. Having begun this soul-searching process, members found themselves disillusioned by the unethical and sometimes criminal activities of their religious leaders. Former members of congregations not registered with the state also stressed their religion's dangerous anti-Soviet ideology and political agenda. ${ }^{45} \mathrm{~A}$ few stories came from believers who renounced religion during 
or after serving time for illegal religious activity or for conscientious objection. ${ }^{46}$ Many believers told readers how they uncovered contradictions in the Bible or in the religion's interpretation of the Scriptures, or both. ${ }^{47}$ In some cases, they formed friendships with non-believers and desired more involvement in their work collectives or communities outside of the religion. ${ }^{48}$ Sometimes atheist agitators won over their trust and slowly convinced them of the falsity of their beliefs. ${ }^{49}$

Narratives of former believers required happy endings as proof that their authors had made the right choice. In most versions, the individual eagerly reentered society, finding fulfillment both in labor and in the broader task of building communism. This had added importance in the Khrushchev era, with the increased demand that all citizens engage in "socially useful labor." Indeed, many believers, primarily clergy, were exiled under a 1961 decree against "parasitism." ${ }^{50}$ Testimonials depicted believers as scorning work and society in favor of preparing for the afterlife. ${ }^{51}$ One man recalled how local Pentecostal leaders spread rumors that the world was about to end, and encouraged members not to bother with secular concerns like work meetings, elections, and military service. ${ }^{52}$ As believers transformed back into Soviet citizens, their hostility to labor morphed into love of work. A Witness who had considered work pointless in the face of Armageddon now had his portrait on the honor board at his job..$^{53}$ Another former believer borrowed the Stalinist slogan "life has become brighter, easier, more joyful" to express his sentiments. ${ }^{54}$

In reality, believers often faced serious discrimination in the workplace, making their job choices limited. Also, while narratives portrayed believers as lacking a strong work ethic, many agitators privately acknowledged the opposite. At a 1963 Komsomol plenum in Moldavia, for example, one attendee noted his own difficulties in working with Baptists at the factories, as they did not smoke, did not drink, and were good workers. He complained that the Komsomol lacked compelling examples from within their ranks to counteract this upstanding image of young Baptists. ${ }^{55}$ In this sense, testimonials served a useful purpose in undermining the positive reputation of Protestants as hard workers.

In short, the conclusion of such narratives was meant to convince current believers that they too could leave religion and begin new, better lives as productive citizens. Almost all began or ended their stories with a message to current members to follow their example..$^{56}$ One former Baptist proclaimed his wishes for those still trapped in religious belief:

I would like them [believers] to free themselves from this religious fog, from falsity and lies, to see the world as it really is, without any interference from nonexistent "supernatural" forces. I want them to see how Soviet people are transforming nature, building hydroelectric stations, farming the virgin lands, how they are selflessly working to build a bright, perfect life for everyone, for all peoples. ${ }^{57}$

Former believers contrasted this idyllic picture of life without religion with their own experiences in religion, which they depicted as utterly devoid of happiness and joy. For one woman, life as a Baptist had been "monotone," but once she discovered atheism, it seemed to her that the birds began to sing more beautifully, the flowers appeared more brightly colored, and she realized she had never been so happy in her entire life. ${ }^{58}$ When the magazine Nauka i religiia received an anonymous letter in 1962 criticizing the publication for attacking religion, which the author argued brought comfort and internal satisfaction to believers, the editors responded by citing multiple former 
believer narratives depicting how miserable life had been for them. ${ }^{59}$ Indeed, expressions of regret and words of warning completed the standard narrative of former believers.

\section{Heaven will be built on Earth!}

The Soviet state published former believer testimonials not only with believers and atheist agitators in mind. In fact, most people reading these stories in the local newspapers belonged to neither category. The state intended these stories to have a prophylactic effect on this wider audience by teaching citizens the dangers of involvement with religious organizations. This had particular relevance in regard to Protestant religions, whose adherents actively proselytized in the Soviet Union to convert new members, and with some success. Atheist narratives offered a potential rebuttal to such efforts. Together with intensified atheist agitation and individual work with believers, these strategies meant to beat Protestant religions at their own game.

Atheist agitators hoped that such stories would help to convince believers and nonbelievers alike that the search for purpose in life could be solved with the discovery of atheism and communism. Yet some accounts suggest the conversion to militant atheism did not always end individuals' existential questions. To begin with, many former believers joined and left several religious organizations prior to renouncing faith altogether. Their life history could not be simply divided into two halves. One man recounted having joined the Baptists, Pentecostals, and the Seventh-Day Adventists before abandoning religion. ${ }^{60}$ Another man had been an old Believer, Baptist, Pentecostal, and Witness. ${ }^{61}$ In other words, many believers had spent time as nonbelievers, but found life without religious faith somehow unsatisfying.

As a result, some former believers admitted to having previously left religious organizations, only to return to them later. Many of them noted how after publicly denouncing Protestantism, they continued to receive visits from their former religious leaders asking them to reconsider. Indeed, atheist propaganda sometimes included complaints that once a believer had been convinced to leave his faith, atheist agitators lost interest in him, viewing the case as resolved. Religious preachers, on the other hand, were often much more persistent in winning back lost sheep and did successfully convince some to return to the organization. In one incident, a young Pentecostal man left the religion in 1971, but returned years later, wanting to reunite with his family and regain his former life. While he was an atheist, his old congregation still helped him build a new home, whereas the local Communist Party youth organization (Komsomol) had been less forthcoming with such assistance. The story concludes by arguing that if Soviet collectives paid more attention to people in need and followed through with former believers, this man's return to religion would never have happened. ${ }^{62}$

Narratives of former believers who had slipped back into religion served as a warning to atheist agitators to appreciate the need for patient, thorough, time-intensive individual work with believers. Many stories dwell on moments where schools and work collectives failed to reach out to believers, or even mocked them for their religious beliefs. Had someone from the community intervened to help them, the former believers suggested, they might have left religion much sooner, or never joined in the first place. Overall, atheist agitation often failed to compete with religious proselytism. One atheist agitator gave an example to illustrate the problem. In the past eight years, activists had held four conversations with a local believer, Semen. During that same time, Semen had spent at 
least eighty hours a month engaged in religious services and activities. ${ }^{63}$ Atheism simply could not hope to win out with this imbalance of energy and resources.

Former believers also co-opted religious proselytism in the tone and style of their testimonials, which often resembled religious language more typically found in stories of conversion to, and not from religion. Believers "confessed" their religious past to a Soviet society with unlimited ability to forgive its repentant citizens. ${ }^{64}$ They described their journeys as searches for "the truth," for a higher meaning or purpose, which they ultimately found in the construction of communism. They maintained that evil does exist in this world and must be defeated, but that it comes out of economic injustice and not from Satan or original sin. One former believer declared that human existence is a "battle of truth against falsity, and the powers of good against the powers of evil." ${ }^{65}$ The stories described how believers began to doubt the teachings of the Bible and turned to antireligious literature for answers. One man related how, after praying to God for help but hearing no response, he read the popular atheist work, The Bible for Believers and NonBelievers, followed by the works of Marx, Lenin, and Herzen, and got the information he needed. ${ }^{6}$ The realization of religion's falsity and communism's truth often came as an "epiphany" that could not be ignored or disputed ${ }^{67}$ Just as joining religion had required a definitive break with the sinful secular world, accepting communism meant a permanent and public rejection of their former religious community.

Narratives depicted communist society as a superior earthly paradise to that promised by Christianity, and one in which admission would be based on hard work, not on faith and prayer. Former believers promised that communism would build this perfect world on earth. ${ }^{68}$ This vow echoed Khrushchev's statements that communism would be achieved in the immediate future. One former Adventist proclaimed that "our "eternal kingdom' is not in heaven" and the "name of that kingdom is communism." Only active builders of communism would gain entrance, he noted. ${ }^{69} \mathrm{~A}$ former Baptist told readers that "paradise needs to be built on earth. Don't wait for it in the afterlife. It's not going to happen." ${ }^{70}$ Life without this secular goal had no meaning, and so believers described their time in religious organizations as utterly wasted and empty. ${ }^{71}$ Through atheism, they were "born again" as Soviet citizens. ${ }^{72}$ The stories further echoed the millennial urgency of conversion, but without the references to Armageddon. One former Witness encouraged other believers: "Do not lose time - join the ranks of builders of communism!" 73

While all the narratives share common themes and are written in a similar style, some differences do emerge between the various Protestant denominations. Former Pentecostals more frequently discussed the damage to mental and physical health caused by speaking in tongues, faith healings, and other rituals, which they described as frightening. ${ }^{74}$ Former Baptists dwelled most heavily on the baptism ritual itself, which was often depicted as a serious health risk. In some instances, believers died or became gravely ill as a result of baptisms in cold water. ${ }^{75}$ For Witnesses, the situation was a bit different, as the Soviet state had banned the group from registering with the government as a religion. Their stories almost always included allegations of the organization's involvement in anti-Soviet activities and its anti-Soviet political ideology. ${ }^{76}$ Witness narratives also included a disproportionate number of believers who had served prison sentences for their religious activity. ${ }^{77}$

These differences helped to create a threat hierarchy, in which Witnesses represented the greatest potential harm for society, and (registered) Baptists the least, a distinction that 
mirrored and reinforced the actual state policy toward these religions. One man, who had been a member of the Baptists, Pentecostals, and Witnesses, wrote in his memoir that the Witnesses were "the most reactionary, base, and despicable" of the three. ${ }^{78}$ A survey of Moldavian press coverage also suggests that newspapers published a disproportionate number of stories on the religions in its locality that it felt were most dangerous. As a result, Moldavian district papers abounded with tales of former Witnesses, despite their relatively small membership. ${ }^{79}$ At the same time, the new religious policy, which dictated attention to local conditions, meant that testimonials did tend to reflect the actual religious diversity of the surrounding community. Thus, while Moldavian and western Ukrainian papers, printed in areas with high concentrations of Witnesses, included hundreds of stories from this religious community, citizens in central Russia may have never heard of the Witnesses at all.

\section{Taking Sides, Dividing Communities}

In line with state religious policy, every narrative proclaimed the loyalty of ordinary believers to the Soviet state. ${ }^{80}$ At the same time, these stories also demonized leaders and so-called "fanatics," who held the blame for recruiting honest Soviet citizens into religion. The image of a spider web enjoyed popularity as a means of illustrating how cunning, predatory leaders trapped unwitting individuals. ${ }^{81}$ Leaders' criminal or hypocritical actions provided a key reason for why believers ultimately rejected Protestantism. Ultimately, if former believers wanted to frame themselves as victims, they needed perpetrators and found them in their preachers, ministers, and church elders. They portrayed these individuals as extortionists, former Nazis or collaborators, thieves, hooligans, rapists, child abusers, adulterers, wreckers, speculators, drunkards, deserters from the Soviet Army, and deadbeats. ${ }^{82}$

If individual believers portrayed their own lives and actions as being in line with Soviet norms, albeit with more personal trauma and less education, they displayed a much different attitude toward their former religious leaders. Here, the testimonials frequently resorted to gross sensationalism, contrasting their own innocence with their leaders' extreme guilt. One Adventist claimed he almost went blind because his religion forced him to avoid daylight at all costs. Having left the religion, he burned his Bible and put up white curtains in his home. ${ }^{83} \mathrm{~A}$ former Witness denounced his own, now deceased wife, whom he recalled put glass and ashes in the neighbors' bread dough when they refused to join the religion. ${ }^{84}$ Another former member recalled how one L'vov leader had raped a fourteen-year-old girl, an accusation that appeared in multiple sources..$^{85} \mathrm{In}$ general, stories from former Witnesses tended to have the greatest quantity and most extreme examples of misconduct, further enforcing the view that this religion posed the greatest risk to Soviet society among Protestant organizations.

The state needed this grisly portrait of rampant amorality to overcome a major hurdle to eliminating Protestant religious communities. These religions' claims of a higher moral code were one of their major attractions for members. They generally preached abstention from alcohol consumption, tobacco use, and sexual activity outside of marriage. Many former believers admitted that the religion's proclaimed high ethical standards had been a major factor in their decision to join. By tarnishing the images of their former pastors and ministers, they exposed religion's moral superiority as a myth. ${ }^{86}$ Most frequently, the narratives include tales of how religious leaders misappropriated 
donations for their own personal benefit. ${ }^{87}$ At the same time, former believer testimonials demonstrated that desirable moral qualities could be found outside of faith communities. One woman noted that she joined the Baptists in large part because of the refuge it provided from her alcoholic husband, who was not a member of the faith. She expressed gratitude that atheist agitators not only convinced her to abandon her faith, but also managed to transform her husband into an upstanding, sober citizen. ${ }^{88}$ One Pentecostal woman recounted how after her husband died in an apartment fire, her work collective immediately provided financial aid and also helped her son attend a summer camp. She credited their kindness as saving her from "religious imprisonment."

Many former believers described Christian ethics as inherently amoral and inferior to Communist ethics. They pointed out that the vaunted principle of unconditional love meant that Christians loved Nazis and saw them as brothers and equals. ${ }^{90}$ Good deeds were portrayed as self-interested actions meant to convince individuals to join the faith. One woman, acknowledging how the Adventists financially supported her after she was fired from her job, chalked up their actions to "selfish" motives. This same person claimed that the concept of forgiveness for sins was tantamount to an endorsement of murder and violence..$^{91} \mathrm{~A}$ former Baptist questioned how his faith could require him to love those American capitalists who were plotting to drop a nuclear bomb on the USSR. 92

While that the Soviet state extended legal registration to many religious organizations, it faced increasing scrutiny starting in the Brezhnev era from foreign observers for its persecution of religious believers. The Soviet press acknowledged complaints from abroad while attempting to justify the need to prosecute certain fanatical and dangerous believers. Official rhetoric maintained that the state prosecuted these individuals not for their religious convictions, but for their illegal, subversive political actions. ${ }^{93}$ For example, the introduction to a 1980 collection of former believer stories justified the recent trial of several Pentecostals as a criminal matter involving illegal activity and in no way connected to the freedom of religious belief guaranteed by the constitution and laws of the USSR. The authors denounced western media coverage as falsely labeling such incidents as examples of religious persecution. It also reassured the reader that most believers are not criminals, but rather sincere and honest people, trapped in a religious "prison." 94

The demonization of religious leaders provided proof that strong measures were needed to protect state and society from such vicious predators, and helped keep the vast majority of Soviet citizens from considering membership in a religious organization. In this, the testimonials aided the goals of the Soviet state. Yet they also undermined efforts to encourage understanding and patience when dealing with sects, particularly when combined with other negative press coverage of Protestant religions. Readers were expected to believe that a reasonable citizen could have joined an antisocial, if not antiSoviet, organization full of seedy characters, and not realized this for several years. Furthermore, if press reports continued to contend that the vast majority of believers fell into the "loyal citizen" category, former believer narratives painted a very different picture, with both leaders and rank-and-file members engaging in unethical or criminal activities. Overall, the distinction between ordinary believers and fanatics or leaders remained murky at best in these accounts. In some instances, the only difference between a fanatic and an ordinary member was that the former still belonged to the religion while the latter no longer did. Thus, in encountering their religious neighbors, 
Soviet citizens may have found it difficult to determine who was "loyal" and who was the "enemy" among them.

Believers themselves found that testimonials created divisions within their families and religious communities. In almost all cases, former believers had family members who were also involved in the religion. Repudiating religion required renouncing one's own parents, wives, husbands, friends, and even children. In short, by pushing for public denunciations of religion, the state ensured the frequent destruction of families. Many youth who grew up in religious organizations only to later reject them told how their parents had kicked them out of their homes and abandoned them to their fate. Some school-age children moved into boarding schools after their antireligious stance made it impossible for them to continue living at home with their families. ${ }^{95}$ Not surprisingly, many believers hesitated to publicly renounce the organization, keeping their loss of faith secret from friends and family. For the Soviet state, this "double life" was not a viable option as it did not further the goals of antireligious agitation, and also made it easier for the former believer to reconsider their decision and return to the faith. Many former believers recount the internal struggle they waged over whether to come forward and tell their community and family about their rejection of religion. ${ }^{96}$

When family conflicts did occur after a public renunciation, former believers generally blamed the religious community for their estrangement, but they could also express bitterness at how their own child, spouse, or parents had chosen faith over family. They recounted how religious leaders taught members to treat former believers as traitors and to cease all contact with them.${ }^{97}$ Some noted that their actions had put a serious strain on their marriage, claiming that believers were inciting their spouses against them. ${ }^{98}$ One 1983 work quoted a young former Baptist who said openly that leaving Baptism was tantamount to leaving behind one's family, and that such a step was extremely difficult. His parents had refused to come to his wedding or to cover the costs unless he returned to the religion. He was instead married with assistance from the local Komsomol. ${ }^{99}$ Former believers often called on their religious family members by name, exhorting them to come to their senses and join them in Soviet society. ${ }^{100}$ One young woman, living apart from her parents and siblings after leaving the Baptists, ended her story by expressing the wish that they will break with religion so that they can all be a happy family again. ${ }^{101}$ Another young man included a plea to his mother, telling her that his door is always open should she decide to renounce her faith as he had done. ${ }^{102}$

To counterbalance the family problems that resulted from leaving religious organizations, testimonials often dwell on how religion itself created dysfunctional families. One former Pentecostal recalled how religious leaders made her break off an engagement with a Red Army soldier and also cease contact with her brother, who had helped to raise her. ${ }^{103}$ Many young people described how their parents forced them to participate in religion and beat them for the slightest disobedience. ${ }^{104}$ The Soviet state hoped that believers reading these stories would recognize how much better life could be without religion, so much so that it would be worth sacrificing friends and family to have a chance at this new, superior existence. The success of such an approach seems doubtful. More likely, the stories kept believers from rejecting religion out of fear of losing their loved ones. Articles in which religious leaders or members threatened former believers only added to this problem. Some included accounts of physical violence against those who left the religion. In one instance recounted in several sources, a man allegedly murdered his wife and mother-in-law after they left the Witnesses, 
burning them alive in their home. For those struggling with doubts about their faith, such an anecdote could hardly have bolstered their courage to publicly announce their rejection of religion. ${ }^{105}$

\section{Conclusion}

Stalin's death ushered in a new era in Soviet religious policy that mixed criminal prosecution with an increased emphasis on agitation and propaganda targeted at rankand-file believers. While state policy toward religion continued to evolve from Khrushchev to Gorbachev, former believer testimonials represent an enduring element of antireligious work in the late Soviet era. Overall, although the post-Stalin press proclaimed that more and more Soviet citizens were leaving "sects" each year, this official rhetoric remained profoundly static. ${ }^{106}$ The testimonials presented the state with a rather serious dilemma. On the one hand, it was hoped that they would make the public less susceptible to religious proselytism. On the other hand, ongoing media attention betrayed the staunch resilience of religious communities, thereby demonstrating the staying power of religion in Soviet society. Thus, the press awkwardly oscillated between highlighting the threat of these religions and proclaiming their gradual and inevitable dissolution. The continued discussion revealed the state's failure to eliminate religious belief, while providing marginal religious organizations with free publicity.

The existence of communities of religious believers who either saw no contradiction between their faith and Soviet ideology, or who refused to integrate into Soviet society belied claims that the Soviet Union had attained advanced socialism. Official discourse attempted to resolve this problem by explaining away religious beliefs as mere "survivals" from the capitalist past that would completely disappear with the achievement of communism. ${ }^{107}$ It portrayed believers as loyal Soviet citizens who had been misled by manipulative fanatics. Equally critical, it shielded the state from having to confront the more dangerous possibility that many of its citizens rejected the official ideology and actually found Protestant religious values and beliefs more appealing than socialism or communism.

Did former believer narratives achieve their goals of encouraging other believers to abandon religion, of making it less likely for others to join, and of convincing the larger populace that most believers were decent Soviet citizens who had just lost their way? The results were mixed for the first goal. In some cases, former believers claimed that other peoples' stories inspired them to also reject religion. ${ }^{108}$ Still, the fact that many stories included plaintive calls to friends and family to break with religion demonstrated that not all believers found these stories convincing. The sensationalist nature of many narratives and authors' tendency to oversimplify or distort beliefs and practices may have made it easier for believers to reject entire stories out of hand. ${ }^{109}$ As a whole, former believers lacked credibility in their communities, having chosen to side with the state so publicly in what was typically seen as an act of betrayal and apostasy. ${ }^{110}$

The state also seemed to have met with mixed results regarding its secular readership, whom it hoped would learn not to get involved with religion, but would help believers in their communities. Undoubtedly, sensationalist press accounts of the evils of Protestantism, including those by former believers, scared most Soviet citizens from associating with these organizations. The success of this effort, however, doomed attempts to convince citizens to trust or accept believers as loyal, honest neighbors. 
Thus, while former believers claimed to have found acceptance in society, until the moment when they left religion, for the public, they remained under suspicion and derision. The narratives themselves include references to the mockery or cold indifference of coworkers, classmates, and neighbors, and laments that no one had reached out a helping hand. ${ }^{111}$ Some recount having been illegally fired from their jobs for their religious beliefs, even while still asserting the freedom of conscience for all believers in the USSR. ${ }^{112}$

Overall, the state succeeded in confining participation in religious communities to a small segment of the population without the level of violence, imprisonment, and exile employed against believers under Stalin. At the same time, the state's end goal had never been containment of religion, but rather its total liquidation as a prerequisite for the achievement of communism. Despite decades of agitation and propaganda work, religion showed no sign of disappearing. It instead became one more hallmark of the failure of progress toward the "heaven on earth" of communism, and another indication of the stagnation of the late Soviet era.

\section{NOTES}

2. This new approach was laid out in a front-page editorial in Pravda in July of 1954. “Shire razvernut' nauchno-ateisticheskuiu propagandu," Pravda, 24 July 1954:1.

3. For example, a 1963 Pravda article stressed the importance of involving former believers in atheist work, and of encouraging them to share their stories and to extort others to follow their example. F. Kaliga, "Ateisty v nastuplenii," Pravda, 7 October 1963: 1.

4. The term "sect" was used as a general descriptor of all Protestant and Old Believer religions.

5. GARF (Gosudarstvennyi arkhiv Rossiiskoi Federatsii - State Archive of the Russian Federation), f. 6991, op. 4, d. 437, 1. 1-3. I include Jehovah's Witnesses as a "Protestant sect" because, while Witnesses do not consider themselves Protestant, Soviet sources included them in this category.

6. In fact, some stories failed to identify a specific religion at all, and many mentioned this information only in passing.

7. This survey includes the newspapers Pobeditel', Iskra, (Riscani district); Bor'ba, Put' $k$ kommunizmu, Leninets (Edinets district); Novaia zhizn' (Briceni district); Iskra (Glodeni district); and Leninets (Lipcani district).

8. For information on the "Hundred Days Campaign," see David E. Powell, Antireligious Propaganda in the Soviet Union: A Study of Mass Persuasion (Cambridge: The MIT Press, 1975), 39; Joan Delaney Grossman, "Khrushchev's Anti-Religious Policy and the Campaign of 1954," Soviet Studies 24, 3 (1973): 274-286. For scholarship on Khrushchev's antireligious campaign, see John Lawrence, "Soviet Policy towards the Russian Churches, 1958-64," Soviet Studies 16, 3 (1965): 276-284; William C. Fletcher and Donald A. Lowrie, 
"Khrushchev's Religious Policy, 1959-1964," in Richard H. Marshall Jr., ed., Aspects of Religion in the Soviet Union, 1917-1967 (Chicago: University of Chicago Press, 1971), 131-156.

9. For information on church closings, see Tatiana A. Chumachenko, Church and State in Soviet Russia: Russian Orthodoxy from World War II to the Khrushchev Years, ed. and trans. Edward E. Roslof (Armonk: M.E. Sharpe, 2002), 187-188; also Nathaniel Davis, "The Number of Orthodox Churches before and after the Khrushchev Antireligious Drive," Slavic Review 50, 3 (1991): 612-620.

10. "Shire razvernut' nauchno-ateisticheskuiu propagandu," 1.

11. Dmitry Pospielovsky, A History of Marxist-Leninist Atheism and Soviet Antireligious Practices (London: Macmillan, 1987), 69-97.

12. The 1961 instructions on registration included a clause barring Pentecostal groups, but later allowed some Pentecostal congregations to register. The bans on Jehovah's Witnesses and Adventist-Reformists remained in place through the late 1980s. GARF, f. 6991 , op. 4, d. 120, 1. 1-12.

13. Joshua Rothenberg, "The Legal Status of Religion in the Soviet Union," in Marshall Jr., ed., Aspects of Religion in the Soviet Union, 1917-1967, 61-102.

14. Fletcher and Lowrie, “Khrushchev's Religious Policy, 1959-1964," 147.

15. William C. Fletcher, Soviet Believers: The Religious Sector of the Population (Lawrence: The Regents Press of Kansas, 1981), 5.

16. Alexei Yurchak, Everything Was Forever, Until It Was No More (Princeton: Princeton University Press, 2006), 14.

17. The November 1954 Communist Party decree on religious propaganda stressed the need for atheist work to be conducted only by qualified cadres. "Postnovlenie TsK KPSS: Ob oshibkakh v provedenii nauchno-ateisticheskoi propagandy sredi naseleniia," Pravda, 11 November 1954: 2.

18. M.T. Kuts, Armageddon (Lviv: Kameniar, 1966), 125-126.

19. In one case, a former prominent Witness became a traveling atheist lecturer, publishing his own memoirs and writing articles for local papers on the dangers of religion for two decades after he renounced his faith. K. Potashov, "Kuda vedet iegovizm," Gudok, 19 May 1964: 4; Idem, Ia i Egova (Uzhgorod: Karpaty, 1966); Idem, Pochemu ia porval s iegovistami (Uzhgorod: Karpaty, 1976); Idem, "Kuda vedet iegovizm;" M. Len'o, “Vystupaet Potashov,” Zakarpatskaia pravda, 15 March 1988: 1.

20. See, for example, GARF, f. 6991, op. 6, d. 960, 1. 13-35; TsDAVO (Tsentral'nyi derzhavnyi arkhiv vyshchykh orhaniv vlady ta upravlinnia Ukrainy - Central State Archive of the Executive Organs of Government of Ukraine), f. 4648, op. 7, spr. 358, ark. 254-255.

21. To cite just one example, a 1959 report from the Council on Religious Cults for Stanislav region in Ukraine boasted that more than 100 Jehovah's Witnesses had recently left the organization and, more importantly, had published items in the press. TsDAHO (Tsentral'nyi derzhavnyi arkhiv hromads'khykh ob'iednan' Ukrainy - Central Archive of Social Organizations of Ukraine), f. 1, op. 70, spr. 2418, ark. 104.

22. An investigation by the city soviet, and a follow-up by the Council on Religious Affairs, rejected the man's complaint. GARF, f. 6991, op. 6, d. 2630, 1. 11.

23. RGANI (Rossiiskii gosudarstvennyi arkhiv noveishei istorii - Russian State Archive of Contemporary History), f. 1, op. 34, d. 77, 1. 19. 
24. Yurchak, Everything was Forever, 122.

25. G. Ul'ianov, “"My otrekaemsia',” Nauka i religiia, 4 (1960): 36.

26. See, for example, A.S. Gerasimets, ed., Nam ne po puti s iegovistami (Irkutsk: Irkutsk Znanie,1960); Elizaveta Petrovna Aksentiuk, “Otrekaius' ot sekty," Iskra, 26 December 1963: 4, (Riscani).

27. See, for example, Fedor Blakhutin, “Trudnyi put' k istine," in A.A. Kruglov and D.M. Matias, eds., Ispoved' pered liud'mi, (Minsk: Belarus', 1978).

28. "Pod maskoi very," Krasnoe znamia, 6 October 1957: 2; M. Iakimov, "Osvobozhdenie ot okov," Novaia zhizn', 24 April 1969: 2, 4.

29. Jochen Hellbeck, Revolution on My Mind: Writing a Diary Under Stalin (Cambridge: Harvard University Press, 2006), 7.

30. Igal Halfin, Stalinist Confessions: Messianism and Terror at the Leningrad Communist University (Pittsburgh: University of Pittsburgh Press, 2009), 10. Halfin's other works also address in detail various forms of self-fashioning and autobiography construction from the 1917 Revolution through the 1930s. See Halfin, Terror in My Soul: Communist Autobiographies on Trial (Cambridge: Harvard University Press, 2003); Intimate Enemies: Demonizing the Bolshevik Opposition, 1918-1929 (Pittsburgh: University of Pittsburgh Press, 2007).

31. Miriam Dobson, Khrushchev's Cold Summer: Gulag Returnees, Crime, and the Fate of Reform after Stalin (Ithaca: Cornell University Press, 2009), 54-55. Golfo Alexopoulos charts similar petitions for reinstatement of rights in the Stalin era. She writes that "In pursuit of their rights, Soviet outcasts discovered how to effectively engage the system and how to construct both a meaningful identity for themselves and a persuasive identity for Soviet officials." Alexopoulos, Stalin's Outcasts: Aliens, Citizens, and the Soviet State, 1926-1936 (Ithaca: Cornell University Press, 2003), 9.

32. The titles reflect this theme. See, for example, Viktor Ivanovich Balaban, "Ia izbral sebe novyi put' [I chose a new path for myself]," Iskra, 6 January 1962: 2 (Glodeni); D. Enii, "Put' k svetu [Path to light]," Novaia zhizn', 18 December 1979: 4; P.F. Syrgi et al., "My nashli vernuiu dorogu [We found the true path]," Iskra, 6 July 1963: 2 (Riscani).

33. A. Mulik, "Put' k pravde," Sovetskaia Moldaviia, 13 June 1957: 3.

34. T. Esina, "Ia poryvaiu s sektoi Baptistov," Sovetskaia Moldaviia, 12 October 1958: 2.

35. Galyna Pryvitna, “Shchastia ditey," Liudyna i svit, 4 (1967): 10-12.

36. See, for example, K.S. Klochkov, Mertvoe ozero (Donetsk: Donbass, 1965), 2-4.

37. One man entitled his work "Stolen childhood:" S. Latyshevich, "Ukradennoe detstvo," in Kruglov, Matias, eds., Ispoved' pered liud'mi, 21-40.

38. P. Dik, “Ne po puti,” Nauka i religiia, 8 (1973): 22-23.

39. Several of these titles were used over and over again. Filipp German, "Ia uvidel svet!," Leninets, 25 March 1962: 4; A. Frantov, "Ot mraka k svetu," L'vovskaia pravda, 3 April 1960: 3; V. Kolesnik, "K svetu," Leninets, 16 July 1963: 2; T. Vagner, “Chetyre goda vo t'me," in E. Iachnik, ed., Pochemu my otrekalis' ot religii (Frunze: Kyrgystan, 1964), 25-27; Nadia Prikhod'ko, "Pobeg iz t'my," in Kruglov, Matias, eds., Ispoved'pered liud'mi, 41-64.

40. See, for example, Esina, "Ia poryvaiu s sektoi Baptistov," 2.

41. The blindfold imagery appears countless times in narratives, and is often used in the titles for such stories. See, for example, B. Boiko, "I upala s glaz pelena... [The blindfold 
fell from my eyes]," Iskra, 22 August 1963, (Riscani); O. Mamchuk, "Z moikh ochei spala poluda [The blindfold fell from my eyes]," Radians'ka Ukraina, 11 February 1960: 4.

42. See, for example, B.A. Duloglo, "Pelena spala s moikh glaz," in N.M. Shilintsev, A.F. Volostnykh, eds., My navsegda porvali s sektoi Baptistov (Kishinev: Kartia Moldoveniaske, 1960), 27.

43. Georgii Iakovlevich Kitik, "Ia snova stal svobodnym chelovekom," Bor'ba, 6 June 1958: 3.

44. See, for example, L. Gromadskii, "Iz mraka na svet," Sovetskaia Moldaviia, 31 October 1959: 2; Aleksandr Stratichuk, "Raduius' zhizni!," Leninets, 3 August 1974: 4; (Edinets) Ivanna Komarinskaia, “Zdravstvui, zhizn'!, L'vovskaia pravda, 28 May 1960: 1.

45. D. Zaporozhan, "Pochemu ia porval s sektoi," Leninets, 28 September 1963: 2, 4, (Edinets).

46. See, for example, P. Geletiuk, "Na sluzhbe Iegovy," Nauka i religiia, 2 (1983): 45-47.

47. See, for example, A. Blank, "Ne opravdalis' prognozy iegovistov," Sovetskaia Kirgiziia, 2 September 1970: 1.

48. Most stories cited multiple factors. See, for example, G.M. Tur'ev, Triasina: rasskaz o cheloveke, porvavshem s religiei (Syktyvkar: Komi kn. izd-vo, 1983), 27-33.

49. For an example of both criminal activity and societal intervention, see I. Lazarev, "Pered sudom rabochei sovesti," Nauka i religiia, 3 (1960): 73, 75.

50. RGANI, f. 5, op. 30, d. 402, 1. 114-117.

51. See, for example, N. Dambitov, “Kto oni, 'bozh'i slugi'?," Sovetskaia Kirgiziia, 25 March 1976: 1

52. Klochkov, Mertvoe ozero, 6-7.

53. Fel'k, “Armageddona ne budet!" 3.

54. Vagner, "Chetyre goda vo t'me," 27.

55. AOSPRM (Arhiva Organizatsiilor Social-Politice din Republica Moldova), f. 278, op. 5, d. $148,1.70-71$.

56. See, for example, F. Banado, "Pochemu ia vyshel iz sekta," Sovetskaia Latviia, 12 May 1959: 2.

57. I.N. Glushak, "Baptizm - Eto lozh' i fal'sh!," in V.I. Golubovich, ed., Pochemu my porvali s religiei, (M.: Gospolitizdat, 1958), 122.

58. O.A. Elizarova, "Prozrenie," in V.L. Novoselov, ed., Kak prekrasen etot mir, posmotri, (Donetsk: Donbass, 1980), 99, 103.

59. L. Laskina, "Rasskazyvaiut byvshie veruiushchie," Nauka i religiia, 9 (1962): 75-77.

60. I.M. Vorokhova and E.V. Mironov, eds., Otravlennoe oruzhie (Rostov on Don: Rostov kn. izd-vo,1966), 56-57.

61. K. Grigor'ev, "V poiskakh very pravednoi," in Kruglov, Matias, eds., Ispoved' pered liud'mi, 132-148

62. The story is appropriately titled, "Everything could have been different." S.K. Latyshevich, "Vse moglo byt' inache," Nauka i religiia, 12 (1983): 28-30.

63. Kuts, Armageddon, 123. 
64. See, for example, I. Buimistruk, Moia ispoved' (Kishinev: Kartia Moldoveniaske, 1961); Kruglov, Matias, eds, Ispoved' pered liud'mi; S.K. Latyshevich, "Ispoved'," Nauka i religiia, 2 (1973): 43-44; D. Zaporozhan, “Ispoved' byvshego sektanta," Novaia zhizn', 27 Jul 1965: 2.

65. Blakhutin, "Trudnyi put' k istine," 19.

66. Igor' Karpovich, “Konchilis' bluzhdaniia v temnote," in Kruglov, Matias, eds., Ispoved' pered liud'mi, 84-85.

67. See, for example, M. Melenevskaia, "Prozrenie," Moskovskaia pravda, 30 July 1960: 2. A. Daniliuk, "Ego prozrenie," Zakarpatskaia pravda, 30 January 1974: 3. V. Kaizer, "Prozrenie," Sovetskaia Kirgiziia, 28 January 1976: 3.

68. Klochkov, Mertvoe ozero, 26. Such sentiments rarely appeared in stories involving Jehovah's Witnesses, as Witnesses preach that God will establish an earthly paradise for his followers, and that only a select 144,000 elite will ascend to heaven.

69. I.P. Petrovskii, "Na priamuiu dorogu," in Golubovich, ed., Pochemu my porvali s religiei, 150.

70. P.G. Kopenkova, "Ne to seichas vremia," in ibid., 87.

71. See, for example, Iu. Zaritovskii and T. Rodionov, "Poteriannaia molodost' [Lost Youth]," Leninets, 26 September 1963: 2, (Edinets); E. Buga, "9 iunykh let poteriano [9 Youthful Years Lost]," Leninets, 17 March 1957: 2, (Lipcani).

72. See, for example, I. Kolodiazhnyy, "Zmii," in M. Khvostin, S. Sholomovich, eds., Perekonue zhyttia, (Stanislav: Stanislav obl. kn. izd-vo, 1962), 81; also, A. Chaikovskii, "Vtoroe rozhdenie [Second Birth]," Leninets, 14 March 1967: 2, (Edinets).

73. Zakharii Gorbul', “Svet poborol t'mu," Leninets, 13 April 1962: 4, (Edinets).

74. S.K. Latyshevich, "Ispoved'," Nauka i religiia, 2 (1973): 43; also, E.V. Khmel', "Schast'e nado dobyvat' trudom," in Golubovich, ed., Pochemu my porvali s religiei, 131.

75. See, for example, I.N. Grushak, "Pochemu ia vyshel iz sekty baptistov," Bor'ba, 31 May 1958; also, V.F. Degtiarenko, Vozvrashchenie k zhizni (Kishinev: Kartia Moldoveniaske, 1961), 7.

76. See, for example, N. Ianitskii, “Ia ne mogu molchat'," Pobeditel', 12 August 1959: 2.

77. This reflected the disproportionate number of Witnesses convicted of crimes related to religious activity relative to the size of their organization. A state study on religious convictions from 1961-1965 listed 1234 total convictions, of which 215 were of Witnesses, 261 of Pentecostals, 350 of unregistered Baptists and Mennonites, and 195 of true Orthodox Christians. The rest came from smaller religious groups. GARF f. 6991, op. 4, d. 173, 1. 180-82.

78. I. Buimistruk, Moia ispoved', 4.

79. In the northern districts of Soviet Moldavia, where the majority of Witnesses lived, the overwhelming majority of articles in district papers on religion concerned the Jehovah's Witnesses.

80. The November 1954 decree by the Communist Party on religious propaganda dictated that believers' political loyalties not be questioned and criticized press coverage that painted believers as politically untrustworthy. "Postnovlenie TsK KPSS: Ob oshibkakh v provedenii nauchno-ateisticheskoi propagandy sredi naseleniia," 2. 
81. See, for example, V. Bromov, "Rvite sektantskuiu pautinu!," Put' k kommunizmu, 17 September 1961: 4; G. Okishor, "Pautina lzhi i obmana..." Novaia zhizn', 19 June 1975: 2; Idem, “V sektantskoi pautine," Novaia zhizn', 13 January 1987: 4.

82. K. Matviichuk, “Krakh 'apostolov’ Iegovy,” Pravda vostoka, 12 June 1969: 4; Shilintsev, Volostnykh, eds., My navsegda porvali s sektoi Baptistov,12-14; V.I. Golubovich, ed. Ne virte 'Svidkam egovy' (Kiev: Molod', 1960), 32-33.

83. Vagner, "Chetyre goda vo t'me," 27.

84. O. Kalendar', “Vera Iegovy - durman,” Leninets, 17 March 1957: 2.

85. Golubovich, ed. Ne virte 'Svidkam egovy', 32-33, 49-51.

86. See, for example, Mykhailo Khomenko, “Teplo sertsia," Liudyna i svit, 7 (1969): 25-27.

87. Vorokhova, Mironov, eds., Otravlennoe oruzhie, 54.

88. E.I. Ivanova, "Pesnia ne umret," in Novoselov, ed., Kak prekrasen etot mir, posmotri, 13, 26-27.

89. M.K. Gerasimuk, “Schast'e skvoz' gorech', in ibid., 53-54.

90. See, for example, V.V. Tikhokhodov, "Pochemu ia ushel iz sekty baptistov," in Shilintsev, Volostnykh, eds., My navsegda porvali s sektoi Baptistov, 32.

91. Vera Gruber, "Pochemu ia porvala s sektantami," in B.I. Gal'perin, I.M. Skliar, N.A. Velichko, eds., Govoriat byvshie veryiushchie (Frunze: Kyrgyzstan, 1969), 25-26.

92. Glushak, “Baptizm - Eto lozh' i fal'sh!," 119-120.

93. See A. Shamaro, “Torgovtsy strakhom i nadezhdoi,” Nauka i religiia, 5 (1963): 29. Also T.P. Korotkaia et al., Iegovizm (Minsk: Nauka i tekhnika, 1981).

94. Novoselov, Kak prekrasen etot mir, posmotri, 5-8.

95. V.F. Dobrzhans'kyy, “Khto vinen?," Liudyna i svit, 10 (1974): 28-29.

96. See, for example, Latyshevich, “Ispoved'," 44.

97. N. Rusnak, “Prozrenie," Zakarpatskaia pravda, 12 February 1977: 3.

98. P. Muzyka, “Vozvrashchenie," Put' k kommunizmu, 8 January 1960: 2.

99. V.N. Arestov, Zhizn' vo lzhi (Khark'ov: Prapor, 1983), 84.

100. See, for example, Stratichuk, "Raduius' zhizni!," 4.

101. Prikhod'ko, "Pobeg iz t'my," 64.

102. I. Paladichuk, "Ia poidu sluzhit' v Sovetskuiu Armiiu," Sovetskoe zaural'e, 13 November 1960: 1 .

103. Novoselov, Kak prekrasen etot mir, posmotri, 48-49

104. O. Dudchenko, "Rozdorizhzhia proydeno," Voyovnychyy ateist, 4 (1964): 20-22.

105. For an account of this story, see R. Pavlushko, “Tragediia v Rosil'noi," Zakarpatskaia pravda, 22 August 1962: 4.

106. For discussion of the alleged "sectarian crisis," see V. Gazhos, "Novye tendentsii v ideologii sovremennogo religioznogo sektantstva," Kommunist Moldavii, 5 (1976): 20; A.V. Belov, "Khristianskoe sektantstvo," Agitator, 9 (1982): 45; Idem, Sovremennoe sektantstvo (M.: Znanie, 1969), 24.

107. See, for example, A. Zalesskii, G.P. Davidiuk, and E.S. Prokoshina, eds., Prichiny sushchestvovaniia i puti preodoleniia religioznykh perezhitkov (Minsk: Nauka i tekhnika, 1965). 
108. See, for example, P. Korzhenevskii, “Ia otrekaius'..." in Iachnik, ed., Pochemu my otrekalis' ot religii, 33-34.

109. One former Baptist, for example, claimed that Baptists cry when a baby is born, and laugh when a relative dies. Vorokhova, Mironov, eds., Otravlennoe oruzhie, 64.

110. Marta Russo, “Ne ver'te iegovistam!," Zakarpatskaia pravda, 4 February 1971: 3.

111. See, for example, A.T. Chernov, "Otrublennaia vetv'," in Golubovich, ed., Pochemu my porvali s religiei, 99; also, L.D. Lepikhov, "Istochnik sveta v nauke," in ibid., 109.

112. See, for example, Karpovich, "Konchilis' bluzhdaniia v temnote," 78.

\section{RÉSUMÉS}

Résumé

Cet article étudie les récits d'anciens croyants publiés depuis les années Hruščëv jusqu'à la période de Gorbačëv. Il s'intéresse en particulier aux anciens protestants, que la propagande athéiste de l'époque a traités de façon disproportionnée. L'article déconstruit ces narrations dans lesquelles les anciens croyants décrivent leur passage de la religion à l'athéisme et au communisme. Ces récits sont davantage considérés comme l'un des aspects d'une tradition soviétique plus large selon laquelle la construction de l'identité et la trajectoire de vie personnelle vont de pair avec l'image idéalisée du nouvel homme soviétique. Ils sont également le reflet d'une insistance renouvelée, de la part du pouvoir poststalinien, sur la nécessité de créer une société sans dieu, libérée de tout vestige de croyance religieuse. Pour l'État soviétique, les rapports publiés de ces anciens croyants prouvaient que la société évoluait véritablement dans cette direction et, par là même, constituaient une incitation, pour les autres croyants, à suivre ces exemples et à embrasser l'athéisme. Enfin, cet article évalue dans quelle mesure ces témoignages ont réussi, ou échoué, dans leur mission d'éradication de la foi.

\section{Abstract}

This article examines former believer narratives from the Khrushchëv to the Gorbachëv era. In particular, it focuses on former Protestants, who received disproportionate coverage in atheist propaganda during this period. The article deconstructs the ways in which former believers described their journey from religion to atheism and communism. These narratives are best seen as one aspect of a broader Soviet tradition of constructing one's identity and personal life trajectory in line with the idealized image of the new Soviet man. They also reflect a renewed emphasis in the post-Stalin era on creating a godless society free of any vestiges of religious belief. For the Soviet state, published accounts by former believers provided proof that society was indeed moving in this direction and offered encouragement to other believers to follow these examples and embrace atheism. Lastly, this article assesses the relative success or failure of these testimonials in eliminating religious faith. 
AUTEUR

\section{EMILY BARAN}

Department of History, University of North Carolina, Chapel Hill 